\title{
Hvor svært er det lige? En undersøgelse af genkendelsen af ord med reducerede segmenter
}

\author{
NICOLAI PHARAO, MIA RIDDER MALMSTEDT \\ \& SELINA VENG
}

\begin{abstract}
Reduceret udtale af ord er meget udbredt i daglig tale, hvilket betyder at lyttere konstant møder ordformer der afviger fra den distinkte, kanoniske udtale. Denne undersøgelse ser på om der er forskel på hvor hurtigt og korrekt lyttere genkender reducerede ordformer sammenlignet med distinkte ordformer. Resultaterne af et auditivt lexical decision-forsøg viser at segmentel reduktion hæmmer forståelsen både når der ses på svartider og svarkorrekthed. De viser desuden at lyttere oftere identificerer højfrekvente ord korrekt, uanset om de er reducerede eller distinkte. Resultaterne diskuteres i forhold til modeller for det mentale leksikon og de faktorer der påvirker tendensen til reduktion i løbende tale. Undersøgelsen er den første af sin art for dansk, og den begrænser sig til at undersøge ord præsenteret $\mathrm{i}$ isolation. Den bør derfor følges op af flere studier der også inddrager fonetisk, syntaktisk og semantisk kontekst.
\end{abstract}

EMNEORD: segmentel reduktion, ordgenkendelse, leksikalsk repræsentation, frekvenseffekt

\section{INDLEDNING}

Tale i afslappede samtalekontekster er ofte karakteriseret af omfattende variation i udtalen af ord. Udover forskelle bestemt af talerens stemme, konsonanternes akustiske detaljer og de nøjagtige vokalkvaliteter indtræffer der en væsentlig type variation som følge af akustisk reduktion: Ord produceres ofte ikke som deres fulde former med alle segmenter tydeligt udtalt, men i stedet som reducerede former med 
forandrede, forkortede eller manglende segmenter, dvs. enkeltlyde. Eksempelvis har det danske ord sådan udtalt distinkt formen ['s $\Lambda$ dan], men kan reduceres til ['s $s \mathrm{~d}_{0} n \underline{1}$ ' $\mathrm{s} \Lambda \mathrm{n} n \underline{\mathrm{s}} \mathrm{s} \Lambda \mathrm{n}$ sṇ s] og former derimellem (Schachtenhaufen 2013).

Segmentel reduktion er et udbredt fænomen i almindeligt talesprog (Johnson 2004; Ernestus \& Warner 2011), og flere undersøgelser bekræfter at segmentel reduktion også er udbredt i dansk spontantale (Schachtenhaufen 2013; Heegård 2013, 2015; Pharao 2010). Segmentel reduktion begrænser sig endda ikke til spontantale. Tucker \& Warner (2011) viser i en undersøgelse af fonetisk variabilitet i lukkelyde i amerikansk engelsk at reducerede former forekommer i alt fra afslappet samtale til kontrolleret ordlisteoplæsning. Reducerede former er med andre ord et uundgåligt fænomen $i$ talesprog.

Mens der findes en relativt omfattende mængde undersøgelser af segmentel reduktion i taleproduktion, er utrænede lytteres perception af reducerede former ikke blevet tildelt megen opmærksomhed, hverken i dansk eller andre sprog. Der findes dog et lille udvalg af undersøgelser: For engelsk og hollandsk er der foretaget en håndfuld undersøgelser der beskæftiger sig med variation i ordfinalt / $\mathrm{t} / \mathrm{ud}$ fra et forståelsesmæssigt perspektiv (Sumner \& Samuel 2005; Mitterer \& Ernestus 2006; Janse et al. 2007). Disse undersøgelser forsøger at belyse repræsentationer i sprogbrugeres mentale leksikon, det ordforråd vi har i hukommelsen, og den eller de processer der skal til for at komme fra det konkrete talte input lytteren modtager, til ordets form som det er lagret i hukommelsen.

Sumner \& Samuel (2005) har således i et semantisk priming-forsøg vist at reducerede ordformer skal transformeres til den distinkte ordform i processeringen af det lydlige input. Det at lyttere er i stand til at rekonstruere distinkte ordformer ud fra et signal med segmentel reduktion, underbygges af Janse et al.s (2007) undersøgelse af processering af reducerede former i hollandsk. Her fandt man at lyttere rekonstruerede / $\mathrm{t} /$ på baggrund af leksikalsk information i hørte ordformer hvor der ingen akustiske spor af et $/ \mathrm{t} / \mathrm{var}$ at finde. Ernestus et al. (2002) har ligeledes vist at hollandske ordformer med høj reduktionsgrad nemt genkendes i deres fulde kontekst (dvs. når de præsenteres $i$ en frase eller en hel sætning), men at reduktion hæmmede 
forståelsen hvis de samme reducerede ordformer blev præsenteret i en begrænset kontekst (dvs. med få segmenter fra de tilstødende ord) eller $\mathrm{i}$ isolation. De viste også at jo større fonetisk afstand der var fra den kanoniske form til den reducerede form, jo sværere havde lytteren ved at genkende ordet. Disse undersøgelser indikerer tilsammen at fulde ordformer, dvs. varianter uden segmentel reduktion, er nemmere at genkende end reducerede former, på trods af at reducerede former for mange ords vedkommende er dem vi som sprogbrugere oftest møder i løbende tale. Dette styrker teorier om leksikalsk repræsentation i det mentale leksikon der bygger på en antagelse om at ordformer er repræsenteret med deres distinkte udtale, og at de varianter vi kender fra spontantale, opstår gennem applicering af regler for forskellige artikulatoriske processer.

I dansk er forholdet mellem reduktion og forstålse hidtil kun blevet undersøgt af Ejstrup og Blom (2015), som så på forståelsen af reducerede over for ikkereducerede ord i konstruerede, men meningsgivende sætningskontekster hos danske sprogbrugere. De fandt at reduceret udtale giver (begrænsede) forståelsesproblemer, og at de mere fremtrædende fonetiske cues i ikkereducerede former ser ud til at fremme forståelsen af især abstrakte leksemer og hjælper til at udrede syntaktisk kompleksitet og semantisk uforudsigelighed. Også for dansk ser det således ud til at genkendelsen af talte ord er nemmere for distinkte former, hvilket igen understøtter modeller for det mentale leksikon der indeholder en høj grad af abstraktion fra det konkrete talesignal. Ingen af de undersøgelser vi har nævnt indtil nu, har imidlertid taget direkte højde for ordenes hyppighed i spontantale. Ordfrekvens er centralt i en anden type modeller for det mentale leksikon, de såkaldte eksemplarbaserede modeller (jf. Pierrehumbert 2001, Johnson 2004). Disse står i kontrast til de abstraktionistiske modeller, idet det her antages at konkrete, faktisk oplevede ordformer lagres ubearbejdede med alle deres fonetiske detaljer. De bygger på den udbredte observation at netop segmentel reduktion forekommer oftere i (meget) hyppigt forekommende ord end $\mathrm{i}$ lavfrekvente ord. For at undersøge graden af abstraktion i repræsentationen af ord i det mentale leksikon er det derfor nødvendigt at inddrage ordfrekvens $i$ undersøgelser af genkendelsen af reducerede former. 


\section{Reduktion og ordfrekvens $i$ taleperception}

Ordfrekvens har i mange undersøgelser af taleproduktion vist sig at spille en rolle i forhold til graden af reduktion sådan at højfrekvente stavelser, ord og syntaktiske konstruktioner i højere grad end lavfrekvente har tendens til at blive reduceret (jf. Jurafsky et al. 2001, Bybee 2002 og Pharao 2010). Derfor er det nærliggende at undersøge om vi som lyttere også forventer at højfrekvente ord vil være reducerede, mens lavfrekvente ord ikke vil være det. Ordfrekvens er imidlertid kun blevet undersøgt i meget få studier af perceptionen af reducerede former. For amerikansk engelsk undersøgte Tucker (2011) om der var en forståelsesforskel mellem ord der indeholdt reduceret /g/ eller / r/, og ord hvor segmenterne var distinkt udtalt. Lyttere hørte nonsensord og ord med et af de to segmenter ordmedialt og skulle afgøre om det de hørte, var et eksisterende engelsk ord eller ej, et såkaldt lexical decisionforsøg. Tucker (2011) fandt at lyttere både svarede mere forkert og var længere tid om at svare når stimulus var reduceret i forhold til distinkt. Segmentel reduktion havde altså en hæmmende effekt på perceptionen. Tucker (2011) undersøgte desuden om ordenes frekvens havde en effekt på svartiden og svarkorrektheden ud fra den hypotese at frekvens kompenserede for reduktion. For de ikkereducerede ordformer fandt han at de højfrekvente forekomster netop var nemmere at processere end lavfrekvente, mens der for de reducerede ord ikke var nogen effekt af ordfrekvens at finde. I et andet forsøg testede Ernestus og Baayen (2007) også om ordfrekvens spillede en rolle i perceptionen af reduktion ved at undersøge hollandske lytteres forståelse af reduktion i præfikser i morfologisk komplekse ord hvor de brugte varighed som mål for grad af reduktion. Deltagerne hørte ord med enten reduceret eller distinkt udtalt præfiks og nonsensord og skulle afgøre om de hørte et eksisterende ord eller ej. Undersøgelsen viste at reduktion gjorde genkendelsen af ord sværere uanset hvor frekvente ordene var. Resultaterne fra disse undersøgelser tyder altså på at der ikke er nogen kompensation for reduktion ved højfrekvente ord, som man ellers kunne forvente (jf. observationen omtalt ovenfor om at hyppige ord oftere indeholder reducerede segmenter end sjældne ord). 
Genkendelse af ord med reduceret intervokalisk / $g / i$ dansk - en eksperimentel undersogelse

Vores undersøgelse tager det første spadestik til en direkte undersøgelse af reducerede formers status i det mentale leksikon hos danske sprogbrugere. Vi undersøger først og fremmest hvordan sprogbrugere genkender reducerede ordformer set i forhold til distinkte ordformer, og vi bruger hertil et auditivt lexical decision-forsøg. Vores hypotese fastsættes på baggrund af tidligere undersøgelser af perceptionen af reduktion (jf. omtalen af Tucker 2011, Ernestus et al. 2002 ovenfor). Vi forventer derfor at danske lyttere oftere svarer forkert på og er længere tid om at genkende ord der indeholder et reduceret intervokalisk /g/ end ord med distinkt udtalt intervokalisk /g/. Et sådant resultat der viser at reduktion har en hæmmende effekt på forståelsen, vil støtte modeller for det mentale leksikon der går ud fra at det mentale leksikon kun indeholder invariante distinkte former af hvert ord. Den længere processeringstid ved de reducerede ordformer som for eksempel Tucker (2011) fandt, kan således tolkes som den tid det tager at matche det konkrete akustiske input over på en abstrakt form, m.a.o. at "oversætte" den reducerede ordform til den abstrakte distinkte form der findes i det mentale leksikon.

Vi undersøger også om ordfrekvens påvirker processeringen af reducerede og distinkte ordformer. Tucker (2011) og Ernestus og Baayen (2007) fandt at ordfrekvens ikke påvirkede processeringen af de reducerede ordformer, altså at lytterne ikke genkendte højfrekvente reducerede ord hurtigere end lavfrekvente reducerede. Det betyder at produktionsmønsteret hiver forventningen i én retning, og perceptionsundersøgelser hiver den $\mathrm{i}$ en anden. Vi vælger derfor at gå mere eksplorativt til værks ved ikke at arbejde med en prædefineret hypotese, men ganske enkelt inkludere ordfrekvens som en faktor $\mathrm{i}$ analysen og se hvordan udfaldet bliver.

Vores undersøgelse bygger på Tucker (2011) og bidrager således til udforskningen af perceptionen af reducerede former $\mathrm{i}$ dansk ved at besvare spørgsmålet:

1) Hvordan processerer sprogbrugere reducerede ordformer set $i$ forhold til distinkte ordformer? 
Vi ønsker desuden at bidrage til debatten om de reducerede formers status i det mentale leksikon. Det gør vi ved at inddrage ordfrekvens i undersøgelsen. For at undersøge dette besvarer vi spørgsmålet:

2) Påvirker ordfrekvens processeringen af reducerede og distinkte ordformer?

Denne artikel begrænser sig dog til at undersøge et enkelt segment $i$ en bestemt kontekst, nemlig reduktion i intervokalisk /g/ fordi undersøgelser af taleproduktion har vist at reduktion er særligt hyppig i denne struktur (se nedenfor).

\section{UNDERSØGELSE AF REDUCEREDE ORDFORMER I DANSK}

Forsogsdesign

Da man ikke kan tilgå det mentale leksikon direkte, må man benytte sig af metoder der undersøger dets struktur indirekte. En anerkendt og ofte benyttet metode til måling af processeringsbelastning og -sværhed er den omtalte lexical decision-opgave. Denne kan være visuel, auditiv eller multimodal. Her tages der udgangspunkt i den auditive udgave. I en auditiv lexical decision-opgave præsenteres informanten for auditive stimuli som han eller hun hurtigst muligt skal identificere som enten rigtige ord eller nonsensord. For at lytteren kan lave en afgørelse om stimulussens ordstatus, skal vedkommende tilgå sit mentale leksikon. Idet leksikon bliver tilgået, kan man indirekte undersøge dets beskaffenhed ved at kigge på reaktionstider og svarkorrekthed (Goldinger 1996).

I forbindelse med forholdet mellem reduktion og forståelse kan den auditive lexical decision-opgave bruges til at klarlægge om der er en forskel på den tid det tager for en lytter at identificere henholdsvis et reduceret ord og et ikkereduceret ord. En reaktionstid der er længere for et reduceret ord end for et ikkereduceret ord, tolkes som tegn på at den reducerede form er sværere at processere fordi lytteren bruger længere tid på at genkende ordet. Omvendt kan en kortere reaktionstid tolkes som at ordet er nemmere at processere fordi lytteren hur- 
tigere kan genkende ordet. Hvis reduktion hæmmer forståelsen, skal man altså forvente længere svartider for de reducerede ord end for de distinkt udtalte ord. Andelen af rigtige og forkerte svar kan ligeledes sige noget om hvorvidt der er en forståelsesforskel mellem reduktion og ikkereduktion; mange forkerte svar tyder på at omkostningerne ved at processere reducerede former er høj fordi ordene ikke genkendes, mens mange rigtige svar indikerer at processeringsbelastningen er lille fordi ordene kan identificeres.

\section{Forsogsdeltagere}

32 informanter med dansk som førstesprog deltog i forsøget. De var alle fra Institut for Nordiske Studier og Sprogvidenskab ved Københavns Universitet og var på første eller andet år af deres bacheloruddannelse. Alle deltagere var mellem 20 og 29 år gamle, gennemsnitsalderen var 22,4 år, og alle angav at de ikke havde nogen form for kendt høretab. Der var 21 kvindelige og 11 mandlige forsøgsdeltagere. Alle informanter fik småkager eller chokolade som tak for at deltage i forsøget.

\section{Materiale}

I et korpusstudie af de danske lukkelyde / b d g/ fandt Pharao (2011) at reduktion langt oftere optræder ordmedialt end det gør ordmarginalt. Han fandt derudover at /g/ var den lukkelyd der havde overvejende størst tendens til at blive reduceret. Derfor fokuserer denne undersøgelse på reduktion i intervokalisk $/ \mathrm{g} /$.

Stimuli bestod udelukkende af tostavede ord med strukturen $\mathrm{CVC}(/ \mathrm{a} / / / \mathfrak{r} /)$ (dvs. konsonant-vokal-konsonant-schwa), som er den hyppigste fonologiske ordstruktur i dansk. Stimuli indeholdt 40 tostavede ord med intervokalisk /g/, for eksempel ligge, og 80 fyldeord, hvoraf 20 var eksisterende danske ord med en anden konsonant end /g/ intervokalisk, fx sniffe, og de resterende 60 ord var nonsensord der overholdt dansk fonotaks, fx skasse. For at undgå at forsøgsdeltagerne skulle finde det påfaldende at kun de rigtige ord indeholdt (reduceret og distinkt) medialt $/ \mathrm{g} /$, besluttede vi at ni ud af de 60 nonsensord også skulle have $/ \mathrm{g} /$ medialt, således både i en distinkt og $\mathrm{i}$ en reduce- 
ret form. I tabel 1 ses en oversigt over de forskellige slags stimuli med eksempler og totalt antal.

TABEL 1. FORDELING AF STIMULI, EKSEMPLER OG ANTAI

\begin{tabular}{lccc}
\hline & Targetord & Fyldeord (rigtige ord) & Nonsensord \\
\hline Eksempel & Ligge & Sniffe & Skasse \\
Antal & 40 & 20 & 60 \\
\hline
\end{tabular}

Alle de rigtige danske ord, såvel targetordene som de eksisterende fyldeord, blev inddelt i grupper efter ordenes frekvens: højfrekvente ord, mellemfrekvente ord og lavfrekvente ord. Det var i sagens natur ikke muligt at dele nonsensordene op på baggrund af frekvens, og det blev kun gjort for de eksisterende danske fyldeord for at sikre at de i denne henseende lignede targetordene, og således at ingen af de to stimulusgrupper adskilte sig ved ordfrekvens.

Inddelingen blev foretaget ud fra en ordfrekvensliste baseret på de sociolingvistiske interview i LANCHART-korpusset (Pharao, upubliceret) der indeholder (logtransformerede) frekvenser for alle ordformer $\mathrm{i}$ et korpus der på det tidspunkt indeholdt 3,1 millioner løbende ord (se Pharao 2010: 146 for detaljer).

\section{Indtaling af stimuli}

Stimuli blev indtalt af en kvindelig taler på 22 der er vokset op i Hellerup. Hun blev informeret om forsøgets formål forud for optagelsen. Lydoptagelsen foregik i et lydisoleret studie på Lingvistisk Laboratorium på Københavns Universitet. Alle ordene blev indtalt i rammesætningen Nair man har hort tror man det er et ord. Ved at lade stimuli optræde lige efter og lige før en koronal lukkelyd, dvs. henholdsvis [d] $\operatorname{og}\left[\mathrm{t}^{\mathrm{s}}\right]$, minimeredes eventuel koartikulatorisk indflydelse på stimuli der skulle præsenteres $i$ isolation. Targetordene og nonsensordene med medialt $/ \mathrm{g} /$ blev indtalt med både reduceret og distinkt udtalt $/ \mathrm{g} /$. Resten af ordene blev kun indtalt distinkt. Indtaleren blev instrueret grundigt i hvordan ordene skulle udtales så de var tydeligt distinkte og tydeligt reducerede. 


\section{Udvalgelse af stimuli}

Til forsøget skulle vi bruge targetord som var entydigt distinkte og entydigt reducerede. Udvælgelsen af ord blev foretaget på baggrund af auditive, visuelle og målbare akustiske kriterier. I Praat (Boersma \& Weenink 2015) blev filerne med optagelserne åbnet og vist med oscillogram og spektrogram. Til at starte med blev alle forekomster segmenteret ud af rammesætningen. Ved hjælp af spektogrammet blev graden af reduktion estimeret ved blandt andet at kigge på tilstedeværelsen af formanter gennem /g/'ets forventede lukke. Formanter indikerer at der er resonans, og eftersom en lukkelyd er karakteriseret ved blandt andet fraværet af resonans, vil tilstedeværelse af formanter gennem en lukkelyd betyde at der ikke er et fuldt lukke, og at lukkelyden altså er reduceret. Andre visuelle kriterier der blev benyttet, var tilstedeværelsen af en lukkeopløsning og ændringer i intensiteten (som den kan betragtes ved hjælp af intensitetskurven i Praat). Figur 1 og figur 2 illustrerer henholdsvis en distinkt og en reduceret form af ordet lukke. I figur 1 (den distinkte form) er der et tydeligt fald i intensiteten under lukkefasen, en synlig opløsning af lukket, og der ses ingen formanter under lukket. I figur 2 (den reducerede form) ses et langt mindre fald i intensiteten, og der er ikke nogen synlig lukkeopløsning. Formanterne fortsætter i modsætning til i den distinkte form gennem hele lukket.

FIGUR 1. OSCILLOGRAM OG SPEKTROGRAM AF LUKKE UDTALT DISTINKT

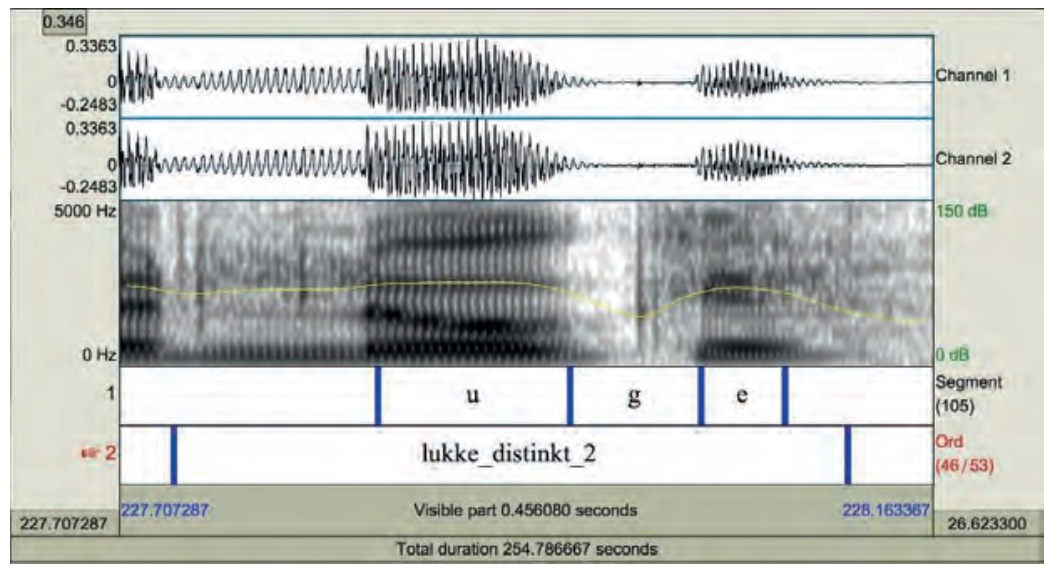

Den horisontale linje $i$ spektrogrammet angiver intensitet målt $i \mathrm{~dB}$. 
FIGUR 2. OSCILLOGRAM OG SPEKTROGRAM AF LUKKE UDTALT REDUCERET

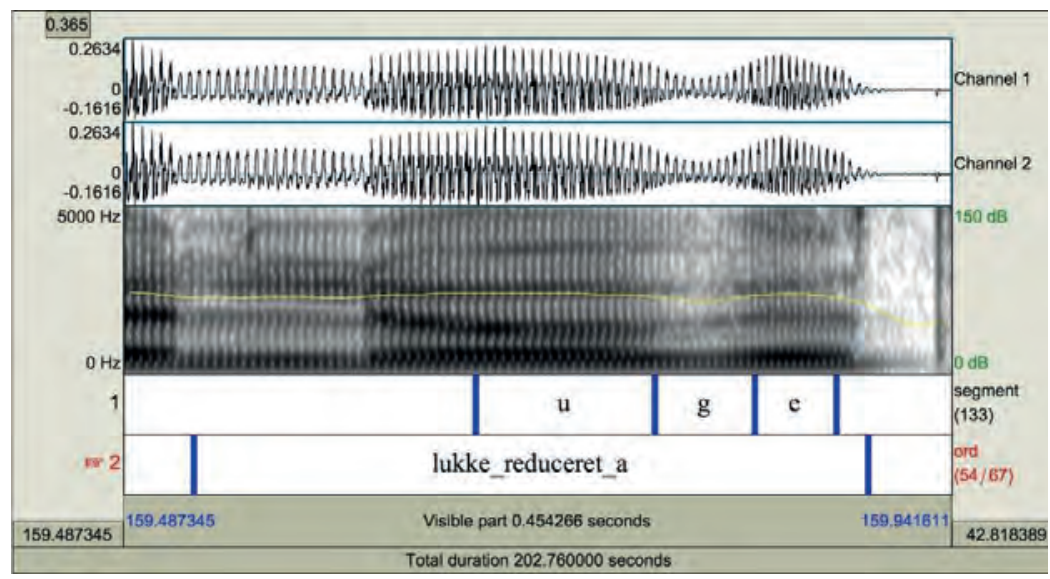

Den horisontale linje $i$ spektogrammet angiver intensitet mailt $i \mathrm{~dB}$.

Efter at have lyttet til ordene og set på ordenes spektrogrammer gik vi videre i udvælgelsesprocessen og brugte målinger af intensitetsforskelle som kriterium for grad af reduktion pa samme måde som det blev gjort i Warner \& Tucker (2011: 1609). Intensitet er lydens styrke i decibel. Vokaler har generelt høj intensitet, mens intensiteten i en kanonisk lukkelyds lukkefase er lig nul. Når en lukkelyd reduceres, opstår der ikke et fuldstændigt lukke, og lukkelyden bliver mere approksimantisk og får højere intensitet. Det er derfor muligt at måle reduktionsgrad i en lukkelyd mellem to vokaler ved at måle forholdet mellem lukkelydens intensitetsminimum og gennemsnittet af de omkringstående vokalers intensitetsmaksima. Hvis der er stor forskel på de omkringstående vokalers gennemsnitlige intensitetsmaksima og lukkelydens intensitetsminimum, er lukkelyden mere distinkt, og hvis der er lille forskel på intensiteterne, er lukkelyden mere reduceret (Tucker 2011). Disse intensitetsberegninger blev foretaget ved hjælp af to Praat-scripts.

\section{Faktorer}

Udarbejdelsen af stimuli giver en ide om at vi arbejder henimod at benytte kategoriske mål for henholdsvis reduktion og ordfrekvens, men eftersom opdelingen i distinkt og reduceret er baseret på intensitetsforskelle og inddelingen i bojfrekvent, mellemfrekvent og lavfrekvent 
på logtransformerede rå frekvenser, er det oplagt også at inddrage disse kontinuerte mål, og det på lige fod med de kategoriske. Lexical decision-opgaven giver to mål for processeringen af reduktion, svartid og svarkorrekthed, og med både intensitetsforskel og en opdeling i distinkt vs. reduceret som mål for reduktionsgrad samt logtransformerede frekvenser og tre frekvensniveauer som mål for ordfrekvens har vi en række afhængige og uafhængige variable der fordeler sig på kontinuerte og kategoriske skalaer. Alle mål er således inkluderet og undersøges i den statistiske analyse af resultaterne. De to typer mål for reduktionsgrad (Reduktion og Intensitetsforskel) er især interessante fordi de klassificerer reduktion som et henholdsvis kategorisk og graduelt fænomen.

\section{Stimulivaliditet - sammenligning med spontantaledata}

For at sikre at vores stimuli og deres grad af reduktion kan siges at være repræsentative for ord i faktisk forekommende spontantale, sammenlignede vi reduktionsgraden i stimuli med reduktionsgraden for samme fænomen hos 10 talere i DanPASS-korpusset (Grønnum 2009).

Figur 3 illustrerer forsøgsmaterialet sammenlignet med dataene fra DanPASS-korpusset. Figuren viser at graden af reduktion i stimuli ligger inden for reduktionsspektret i DanPASS-samtalerne, dvs. at graderne af reduktion i stimuli kan forventes at optræde i naturlig tale.

FIGUR 3. DISTRIBUTIONEN AF INTENSITETSFORSKELLE FOR MEDIALT /G/
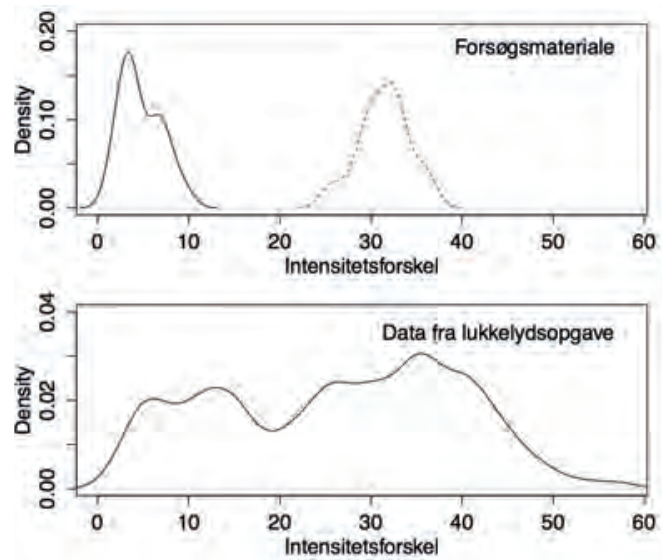

Den overste graf viser intensitetsforskelle $i$ forsogsmaterialet, den nederste $i$ data fra DanPASSsamtaler. Den stiplede linje $i$ det overste billede markerer distinkt udtale. 


\section{Fremgangsmåde}

Forsøgsdeltagerne blev inddelt i to grupper der blev præsenteret for hver sin liste af stimuli. Listerne var designet sådan at den enkelte forsøgsdeltager kun hørte enten den distinkte eller den reducerede form af det samme ord. Hvis informanterne i stedet var blevet udsat for samme ord i begge udgaver, ville der være risiko for en priming-effekt, dvs. at informanter potentielt vil kunne processere anden forekomst af ordet hurtigere fordi de allerede havde hørt det én gang tidligere i forsøget. Hver liste indeholdt således $50 \%$ reducerede targetord og $50 \%$ distinkte targetord. Fyldeordene var de samme på begge lister. Forsøgsprogrammet sørgede for at listerne blev randomiseret for hver forsøgsperson sådan at der blev kontrolleret for en potentiel effekt af rækkefølge. Alle stimuli blev præsenteret over høretelefoner. For hver stimulus skulle forsøgspersonerne afgøre om ordet var et rigtigt dansk ord eller et nonsensord ved at trykke på en af to taster på tastaturet. For den ene halvdel af forsøgsdeltagerne var Ja-knappen placeret ved deres "gode" hånd (for de flestes vedkommende højre hånd) og Nejknappen placeret ved deres "dårlige" hånd, mens den anden halvdel af forsøgsdeltagerne havde Ja-knappen ved den "dårlige" hånd og Nejknappen ved den "gode" hånd. Deltagerne blev bedt om at sidde med en hånd på hver tast, men tasterne havde også fået en særlig markering så de var nemme at finde. I midten af computerskærmen var der et fikseringskryds som havde til formål at holde forsøgsdeltageren fokuseret under opgaven sådan at deres blik ikke vandrede fra skærmen, og de blev optaget af noget andet. Under krydset var der to bokse hvori der var skrevet henholdsvis $J a$ og Nej. Sådan blev det sikret at forsøgsdeltageren hele tiden havde mulighed for at se i hvilken side Ja-knappen og Nej-knappen befandt sig på tastaturet. Når et ord blev præsenteret for forsøgsdeltageren, havde han eller hun 1500 millisekunder til at svare, og blev der ikke svaret inden de 1500 millisekunder var gået, gik programmet videre til det næste ord. Deltagerne blev instrueret $i$ at svare hurtigst muligt, men samtidig at forsøge at undgå at lave fejl. Instruktioner til opgaven blev både givet mundtligt og med en introduktionstekst på computerskærmen. Forsøget indledtes med en træningsrunde med otte ord indtalt af en anden end den person der havde indtalt 
stimuli. Efter prøverunden havde forsøgsdeltageren mulighed for at stille spørgsmål til forsøgslederen inden den rigtige opgave startede.

\section{RESULTATER}

De 32 forsøgsdeltageres data gav i alt 3840 svar. Ud af disse var 2560 svar på fyldeordene, som blev sorteret fra. Desuden frasorteredes svar der overskred grænsen på 1500 millisekunder samt svar med svartider der var kortere end 220 millisekunder i overensstemmelse med praksis hos Tucker (2011). Vi endte således med et datasæt på 1215 svar.

Resultaterne for reaktionstider og svarkorrekthed blev analyseret $\mathrm{i}$ statistikprogrammet $\mathrm{R}$ ved hjælp af henholdsvis lineær regression og logistisk regression. Datasættet blev testet med en række modeller med blandede effekter (også kaldet mixed models) der tillader kontrol for tilfældige effekter, som $\mathrm{fx}$ de specifikke deltagere, når man ønsker at undersøge faste effekter som fx reduktionsgrad eller ordfrekvens. De faste effekter var: Reduktion, Intensitetsforskel, Frekvensniveau og Logtransformeret frekvens, og de tilfældige effekter var: Forsøgsdeltager og Item. Herved justeredes for indflydelsen fra enkeltpersoner og enkelte stimuli i signifikansberegningen og estimatet for de faste effekter (jf. Baayen 2008 og Johnson 2008). Modellerne inkluderede desuden krydseffekter for Reduktion og Frekvensniveau, Reduktion og Logtransformeret frekvens, Intensitetsforskel og Frekvensniveau og Intensitetsforskel og Logtransformeret frekvens. Ingen af disse krydseffekter viste sig at være statistisk signifikante, hvilket betyder at der ikke var nogen (statistisk signifikant) forskel på hvordan ordfrekvens påvirkede henholdsvis reducerede og distinkte ordformer.

I det følgende gennemgås de statistiske modeller, først for svartiderne og derefter for rigtige og forkerte svar.

\section{Svartider}

Svartiden kan fortælle os om lyttere skal bruge mere tid på at finde den passende ordform i deres mentale leksikon når de hører en reduceret ordform end når de hører en distinkt. For at analysere hvordan reduktion og ordfrekvens påvirkede den tid forsøgsdeltagerne var om at genkende ord, lavede vi blandede modeller ved hjælp af linexr regression. 
For de to uafhængige variable, reduktionsgrad og ordfrekvens, havde vi både kategoriske mål og kontinuerte mål, hvilket gav os mulighed for at lave fire forskellige kombinationer af de faste effekter. Derfor lavede vi fire forskellige modeller: 1. med Reduktion (reduceret/distinkt) og Frekvensniveau (lavfrekvent/mellemfrekvent/højfrekvent) som faste effekter, 2. med Reduktion (reduceret/distinkt) og Logtransformeret frekvens som faste effekter, 3. med Intensitetsforskel og Frekvensniveau (lavfrekvent/mellemfrekvent/højfrekvent) som faste effekter og 4. med Intensitetsforskel og Logtransformeret frekvens som faste effekter (se tabel 2).

TABEL 2. OVERSIGT OVER KOMBINATIONER AF UAFHÆNGIGE VARIABLE I MODELLER FOR SVARTIDER

\begin{tabular}{|c|c|c|c|}
\hline & & Frekvens & \\
\hline & & Kategorisk & Kontinuert \\
\hline \multirow[t]{2}{*}{ Reduktion } & Kategorisk & $\begin{array}{l}\text { Model 1: } \\
\text { Reduktion og Frekvens- } \\
\text { niveau som faste effekter }\end{array}$ & $\begin{array}{l}\text { Model 2: } \\
\text { Reduktion og Logtrans- } \\
\text { formeret frekvens som } \\
\text { faste effekter }\end{array}$ \\
\hline & Kontinuert & $\begin{array}{l}\text { Model 3: } \\
\text { Intensitetsforskel og } \\
\text { Frekvensniveau som } \\
\text { faste effekter }\end{array}$ & $\begin{array}{l}\text { Model 4: } \\
\text { Intensitetsforskel og } \\
\text { Logtransformeret frekvens } \\
\text { som faste effekter }\end{array}$ \\
\hline
\end{tabular}

TABEL 3. SVARTID MED REDUKTION OG FREKVENSNIVEAU SOM FASTE EFFEKTER (MODEL 1 I TABEL 2)

\begin{tabular}{|l|l|l|l|}
\hline Faste effekter & Estimat & Standardfejl & t-værdi \\
\hline (Skæringspunkt) & 484,06 & 29,84 & 16,2 \\
\hline Reduktion (reduceret ift. distinkt) & 94,5 & 18,03 & 5,2 \\
\hline Frekvensniveau (lavfrekvent ift. mellemfrekvent) & 72,51 & 27,63 & 2,6 \\
\hline Frekvensniveau (højfrekvent ift. mellemfrekvent) & 56,35 & 27,61 & 2,0 \\
\hline Frekvensniveau (højfrekvent ift. lavfrekvent) & $-16,15$ & 28,17 & $-0,6$ \\
\hline
\end{tabular}

Tabellen har forst 'mellemfrekvent' som referenceniveau og derefter 'lavfrekvent'. 
Tabel 3 viser et resumé af den første model, der har kombinationen Reduktion og Frekvensniveau som faste effekter. Et positivt estimat angiver at svartiderne var længere, og dermed at ordene var sværere at genkende, mens et negativt estimat angiver at svartiderne var kortere, det vil sige at ordene nemmere kunne genkendes. Dette angives i forhold til et referenceniveau for den pågældende faktor, altså for Reduktion angives effekten for ord med reduceret $/ \mathrm{g} / \mathrm{i}$ forhold til ord med distinkt /g/ (i alle modelresuméer er referenceniveauet skrevet til sidst i parentesen efter benævnelsen af faktoren). $T$-værdien er et mål for resultatets statistiske signifikans, og $t$-værdiens numeriske værdi skal være højere end 2 eller lavere end -2 for at resultatet er statistisk signifikant (Baayen 2008: 248). Vi kan således uddrage fra tabel 3 at ordene havde længere svartider, hvilket vil sige at de var sværere at genkende når de var reducerede end når de var distinkte. Tabellen viser desuden at mellemfrekvente ord havde kortere svartider (var nemmere at genkende) end både lavfrekvente og højfrekvente ord. Begge disse sammenhænge er statistisk signifikante ( $t=5,240$ for Reduktion, $t=2,624$ og $\mathrm{t}=2,041$ for hhv. lavfrekvent og højfrekvent ift. mellemfrekvent for Frekvensniveau). Ser man på forholdet mellem de lavfrekvente ord og de højfrekvente ord, er der derimod ingen statistisk signifikant forskel.

Figur 4 demonstrerer den effekt reduktion og ordfrekvens har på svartiderne. Plottet til venstre viser Svartid som en funktion af Reduktions to niveauer, distinkt og reduceret. Man kan se at svartiden for de reducerede ord er knap 100 millisekunder længere end svartiden for de distinkte ord. Plottet til højre viser Svartid som en funktion af Frekvensniveaus tre niveauer, højfrekvent, mellemfrekvent og lavfrekvent, hvor man kan se en u-formet kurve forme sig fra lav- til højfrekvent sådan at mellemfrekvente ord har en kortere svartid end lav- og højfrekvent som har svartider der ligger meget tæet på hinandens. 

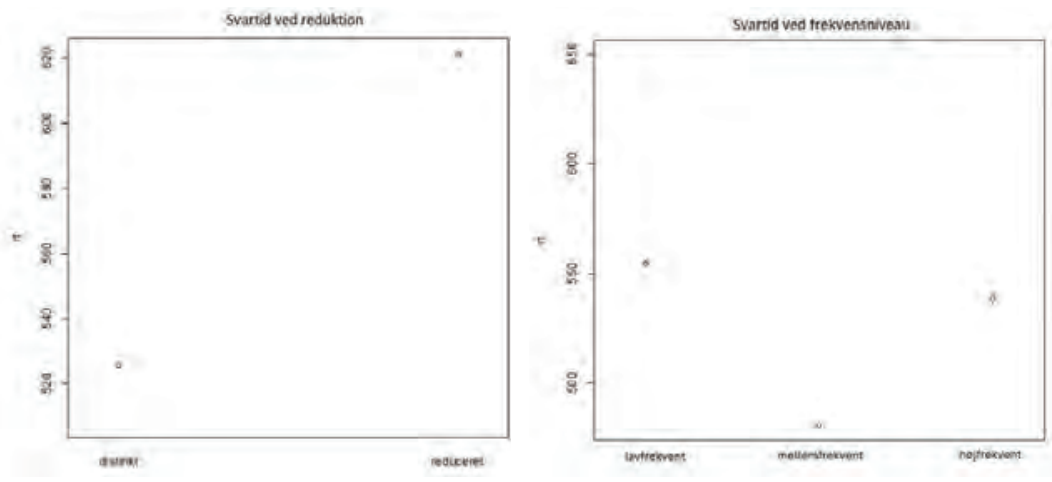

Vi testede også en model med det kontinuerte mål for ordfrekvens (model 2 i tabel 2), Logtransformeret frekvens. Her fandt vi også at reduktion havde en effekt på svartiden $(t=5,1)$, men vi fandt ingen effekt af Logtransformeret frekvens $(t=-0,6)$. Dette er ikke overraskende set $i$ lyset af at det kun var mellemfrekvente ord der havde en kortere reaktionstid, jf. figur 4 . Vi vender tilbage til denne effekt i diskussionen af resultaterne.

TABEL 4. SVARTID MED INTENSITETSFORSKEL OG FREKVENSNIVEAU SOM FASTE EFFEKTER (MODEL 3 I TABEL 2)

\begin{tabular}{llll}
\hline & Estimat & Standardfejl & $t$-værdi \\
& & & \\
(Skæringspunkt) & 593,64 & 30,91 & 19,2 \\
Intensitetsforskel & $-3,47$ & 0,66 & $-5,3$ \\
Frekvensniveau (lavfrekvent ift. mellemfrekvent) & 76,44 & 27,79 & 2,8 \\
Frekvensniveau (højfrekvent ift. mellemfrekvent) & 54,49 & 27,76 & 1,9 \\
Frekvensniveau (højfrekvent ift. lavfrekvent) & $-21,95$ & 28,35 & $-0,8$ \\
\hline
\end{tabular}

Tabellen har forst 'mellemfrekvent' som referenceniveau og derefter 'lavfrekvent'.

Den tredje model (model 3 i tabel 2) kombinerer det kategoriske mål for frekvens, Frekvensniveau, med det kontinuerte mål for reduktion, Intensitetsforskel. I resumeet i tabel 4 kan man se at Intensitetsforskel påvirker svartider sådan at jo højere ordenes intensitetsforskel er, jo hurtigere genkendes ordene $(\mathrm{t}=-5,2)$. Det vil sige at de distinkte ord (med høj intensitetsforskel) var nemmere at forstå end de reducerede ord (med lav intensitetsforskel). Intensitetsforskel, som jo er et fin- 
kornet mål for graden af reduktion, er altså et mindst lige så godt mål for reduktion som det grovkornede mål med en binær opdeling i reducerede og distinkte udtaler af ord. Figur 5 illustrerer den effekt intensitetsforskel har på svartiderne; man kan se at Svartid er lineært aftagende idet Intensitetsforskel stiger, altså den påviste effekt at ord bliver nemmere at genkende når de har en højere forskel i intensitet og altså er mere distinkte.

I denne model bliver mellemfrekvente ord ligesom i den første model genkendt hurtigere end lavfrekvente og højfrekvente ord, men hvor begge forskelle i den første model var statistisk signifikante, er kun forskellen mellem lav- og mellemfrekvent signifikant her $(\mathrm{t}=2,8)$, mens den mellem høj- og mellemfrekvent netop ikke når det påkrævede signifikansniveau $(t=1,9)$. Der er heller ingen signifikant forskel på høj- og lavfrekvent.

FIGUR 5. SVARTID SOM FUNKTION AF INTENSITETSFORSKEL

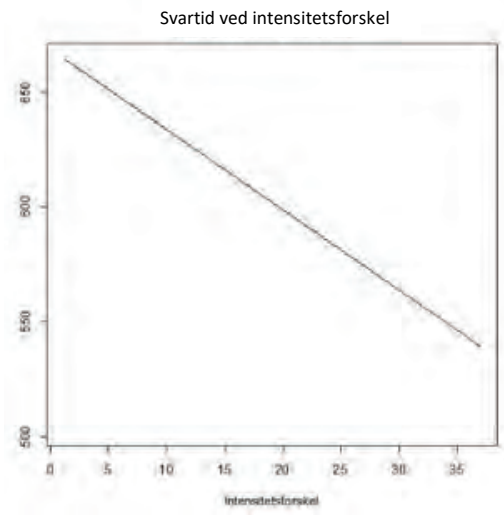

Vi testede også en model for Svartid hvor vi kombinerede de to kontinuerte mål for reduktionsgrad og ordfrekvens, Intensitetsforskel og Logtransformeret frekvens (model $4 \mathrm{i}$ tabel 2). Her havde Intensitetsforskel igen en statistisk signifikant effekt $(\mathrm{t}=-5,2)$, men heller ikke her havde Logtransformeret frekvens en statistisk signifikant effekt ( $t=$ $0,8)$. Det tyder på at en inddeling i niveauer er en bedre repræsentation af ordfrekvens når svartider skal modelleres. For at opsummere: Svar- 
tiderne bliver kortere når intensitetsforskellen stiger. Distinkt udtalte ord er altså nemmere at processere end reducerede, hvilket vil sige at reduktion hæmmer processeringen.

\section{Svarkorrekthed}

Som for Svartid lavede vi for Svarkorrekthed blandede modeller for at analysere om og hvordan reduktion og ordfrekvens påvirkede sandsynligheden for at lytterne svarede korrekt på stimuliene. Da der her er tale om kategorielle svar, vil data blive analyseret med logistisk regression med blandede effekter. Vi arbejdede med de samme uafhængige variable (Reduktion, Intensitetsforskel, Frekvensniveau og Logtransformeret frekvens) og kunne derfor ligesom $i$ analysen af svartiderne lave fire forskellige kombinationer af variablene og dermed også fire modeller (se tabel 2 under afsnittet Svartider).

TABEL 5. MODEL FOR SVARKORREKTHED MED REDUKTION OG FREKVENSNIVEAU SOM FASTE EFFEKTER

\begin{tabular}{l|l|l|l}
\hline & Estimat & Standardfejl & $p$-værdi \\
\hline (Skæringspunkt) & 5,03 & 0,62 & $<0,001$ \\
Reduktion (reduceret ift. distinkt) & $-1,57$ & 0,44 & $<0,001$ \\
Frekvensniveau (lavfrekvent ift. mellemfrekvent) & $-1,39$ & 0,63 & 0,03 \\
Frekvensniveau (højfrekvent ift. mellemfrekvent) & $-0,1$ & 0,67 & 0,88 \\
Frekvensniveau (højfrekvent ift. lavfrekvent) & 1,29 & 0,64 & 0,043 \\
\hline
\end{tabular}

Tabellen har forst 'mellemfrekvent' som referenceniveau og derefter 'lavfrekvent'.

Den første model for svarkorrekthed er givet i tabel 5, hvor de benyttede uafhængige variable er de to kategoriske mål for henholdsvis reduktionsgrad og ordfrekvens, Reduktion og Frekvensniveau. Er estimatet positivt, betyder det at ordene i forhold til referenceniveauet har større sandsynlighed for at blive bedømt korrekt. Derimod angiver et negativt estimat det modsatte, altså at ordene har mindre sandsynlighed for korrekt svar end ved referenceniveauet. $P$-værdien er et udtryk for om resultatet er statistisk signifikant, og for at et resultat har opnået signifikans, skal værdien være under 0,05 .

Resumeet af modellen viser at reducerede ord har højere sandsynlighed for at blive bedømt forkert end ikkereducerede, hvilket er en signi- 
fikant sammenhæng ( $p<0,001)$. Andelen af rigtige og forkerte svar for henholdsvis distinkte ord og reducerede ord er angivet i figur 6, hvor man kan se at andelen af forkerte svar er højere og antal korrekte svar lavere for reducerede ord end for distinkt udtalte ord. Reduktionen virker altså hæmmende på ordidentifikationen. Man kan dog bide mærke $i$ at der hverken for reducerede eller distinkte ordformer er særligt mange forkerte svar i forhold til antallet af rigtige svar; for de distinkte ord er fejlraten på 4,4\% mens 10,8\% af svarene for de reducerede ord er forkerte. Med hensyn til Frekvensniveau er mellemfrekvente ord, ligesom i modellerne for Svartid, nemmere at processere (det vil sige at de har større chance for korrekt svar) end lavfrekvente $(p=0,03)$, mens der ikke er nogen signifikans ved forskellen mellem høj- og mellemfrekvente ord. Der er dog en signifikant forskel på høj- og lavfrekvente ord hvor højfrekvente ord har større sandsynlighed for at blive korrekt bedømt end de lavfrekvente har $(p=0,043)$. I figur 7 er der for hvert frekvensniveau angivet antal rigtige og forkerte svar ud fra hvilke man kan se at mellemfrekvente ord har færrest forkerte $(4,4 \%)$ og flest korrekte svar. Man kan desuden se at lavfrekvente ord har langt flest forkerte $(13,3 \%)$ og færrest korrekte svar. Højfrekvente ord placerer sig mellem de mellem- og lavfrekvente ord, men med en fejlrate tættere på de mellemfrekventes på 5,3\%. Det er altså de lavfrekvente ord der er hovedårsagen til de forkerte svar i figur 6.

FIGUR 6. SVARKORREKTHED SOM FUNKTION AF REDUKTION

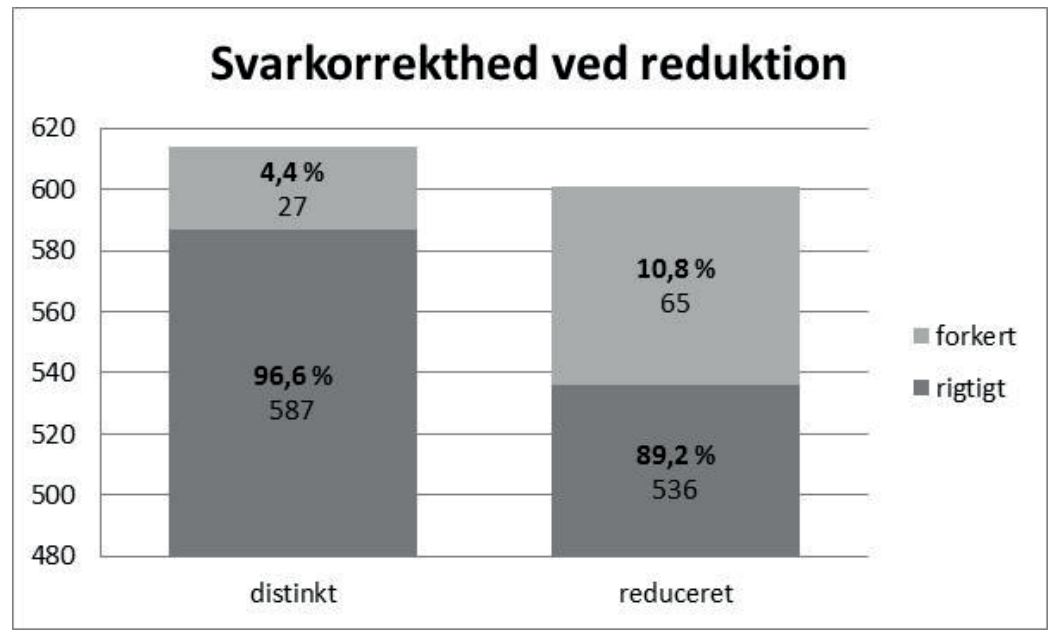




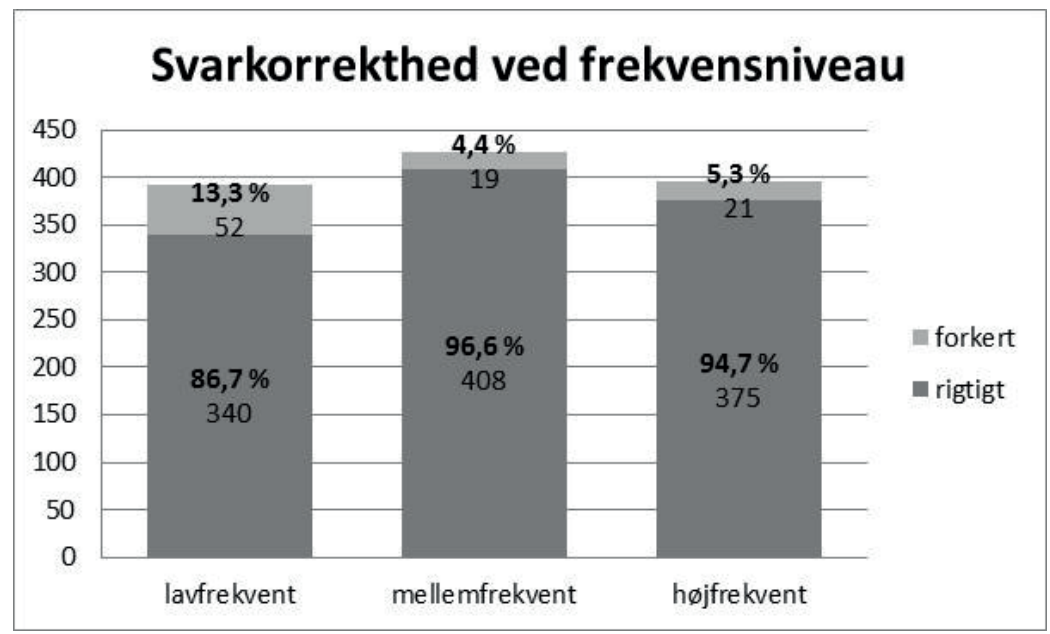

TABEL 6. MODEL FOR SVARKORREKTHED MED REDUKTION OG LOGTRANSFORMERET FREKVENS SOM FASTE EFFEKTER

\begin{tabular}{l|lll}
\hline & Estimat & Standardfejl & $p$-værdi \\
\hline (Skæringspunkt) & 9,06 & 1,94 & $<0,001$ \\
Reduktion (reduceret ift. distinkt) & $-1,6$ & 0,46 & $<0,001$ \\
Logfrekvens & 0,89 & 0,35 & 0,012 \\
\hline
\end{tabular}

Den anden model har en kontinuert variabel som udtryk for ordfrekvens, Logtransformeret frekvens, frem for et kategorisk mål. Resumeet i tabel 6 viser at der også i denne model er en signifikant forskel på hvor høj sandsynligheden er for at svare rigtigt på reducerede over for distinkt udtalte ord, nemlig at lyttere har større sandsynlighed for at svare forkert på reducerede ord end distinkte $(p<0,001)$. Logtransformeret frekvens er desuden, i modsætning til de modeller for Svartid der inddrog den, signifikant i denne model sådan at chancen for at svare rigtigt stiger når frekvensen stiger $(p=0,012)$. Denne sammenhæng mellem Svarkorrekthed og Logtransformeret frekvens ses illustreret i figur 8 , der viser at sandsynligheden for at svare korrekt øges når et ords frekvens ligeledes forhøjes. Figuren viser desuden at sandsynligheden for at svare forkert i det hele taget er forholdsvis lille, som figur 6 og figur 7 også illustrerer. 
FIGUR 8. SANDSYNLIGHEDEN FOR AT SVARE KORREKT SOM FUNKTION AF LOGTRANSFORMERET FREKVENS

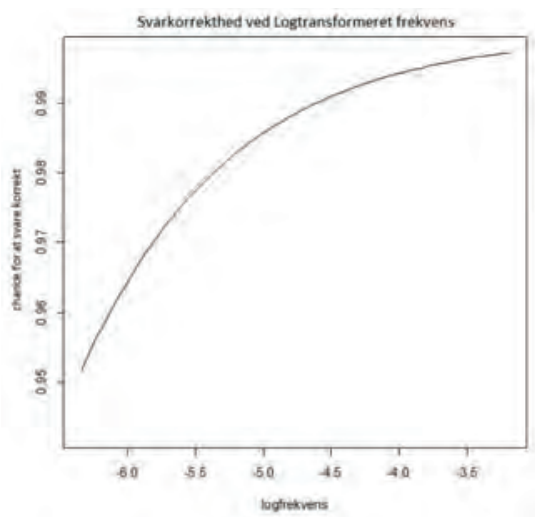

TABEL 7. MODEL FOR SVARKORREKTHED MED INTENSITETSFORSKEL OG FREKVENSNIVEAU SOM FASTE EFFEKTER

\begin{tabular}{l|l|l|l}
\hline & Estimat & Standardfejl & $p$-værdi \\
\hline (Skæringspunkt) & 3,23 & 0,56 & $<0,001$ \\
Intensitetsforskel & 0,06 & 0,02 & $<0,001$ \\
Frekvensniveau (lavfrekvent ift. mellemfrekvent) & $-1,44$ & 0,63 & 0,021 \\
Frekvensniveau (højfrekvent ift. mellemfrekvent) & $-0,05$ & 0,67 & 0,94 \\
Frekvensniveau (højfrekvent ift. lavfrekvent) & 1,39 & 0,64 & 0,029 \\
\hline
\end{tabular}

Forst med 'mellemfrekvent' som referenceniveau og derefter med 'lavfrekvent'.

I den tredje model er Intensitetsforskel, det kontinuerte mål for reduktionsgrad, kombineret med Frekvensniveau, det kategoriske mål for frekvens. Modelresumeet (tabel 7) viser at sandsynligheden for at svare korrekt stiger når intensitetsforskellen bliver større, på samme måde som i modellerne for Svartid, og at sammenhængen er signifikant $(p<0,001)$. Ordprocesseringen er altså påvirket af ordets reduktionsgrad, sådan at en større grad af reduktion mindsker chancen for at svare korrekt. Dette er illustreret i figur 9 som igen tydeliggør at sandsynligheden for at svare forkert ikke er specielt stor. Frekvensniveau følger samme mønster som i den første Svarkorrekthedsmodel; mellemfrekvente ord har større sandsynlighed for at blive bedømt korrekt og genkendes derfor nemmere end lavfrekvente ord $(p=0,021)$, mens der ikke er nogen signifikant forskel på mellem- og højfrekvente ord. 
Det er der til gengæld mellem høj- og lavfrekvente ord, hvor der ved de højfrekvente er større sandsynlighed for at svare korrekt $(p=0,029)$.

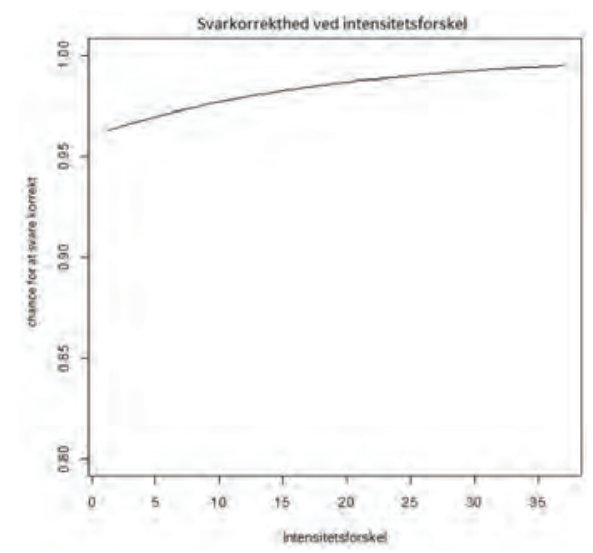

TABEL 8. MODEL FOR SVARKORREKTHED MED INTENSITETSFORSKEL OG LOGTRANSFORMERET FREKVENS SOM FASTE EFFEKTER

\begin{tabular}{l|lll}
\hline & Estimat & Standardfejl & $p$-værdi \\
\hline (Skæringspunkt) & 7,46 & 1,88 & $<0,001$ \\
Intensitetsforskel & 0,06 & 0,02 & $<0,001$ \\
Logfrekvens & 0,94 & 0,36 & 0,009 \\
\hline
\end{tabular}

Den fjerde og sidste model har de to kontinuerte mål for henholdsvis reduktionsgrad og ordfrekvens, Intensitetsforskel og Logtransformeret frekvens, som faste effekter. Resumeet af modellen i tabel 8 viser som i den tredje model at Intensitetsforskel har en effekt på processeringen af ord sådan at jo større intensitetsforskel (dvs. jo mere "distinkthed"), jo større sandsynlighed er der for at svare korrekt på et ord $(p<0,001)$, mens mindre intensitetsforskel, det vil sige større reduktionsgrad, hæmmer evnen til at svare rigtigt. Det betyder at det kontinuerte mål for reduktion, Intensitetsforskel, er mindst lige så godt som det binære mål, Reduktion, i modelleringen af svarkorrekthed. Det samme gjaldt i modellerne for svartid, og tilsammen peger det på at segmentel reduktion bør ses som et graduelt mål, snarere end 
et diskret. Logtransformeret frekvens og Intensitetsforskel udviser i denne model samme (signifikante) sammenhæng som Logtransformeret frekvens og Reduktion i model 2; når et ords frekvens stiger, stiger sandsynligheden for at svare korrekt $(\phi=0,009)$.

\section{DISKUSSION}

Målet med denne undersøgelse var overordnet at undersøge om - og i så fald hvordan - fonetisk reduktion påvirker sprogbrugeres perception. Resultaterne af undersøgelsen demonstrerer at processeringen af ord hørt i isolation bliver påvirket af segmentel reduktion: Både i modeller for svartider og svarkorrekthed var reduktion signifikant. Det vil sige at lyttere hurtigere og med færre fejl kunne genkende ord der indeholdt distinkt /g/ end ord der indeholdt reduceret /g/. Undersøgelsens resultater bekræfter således vores hypotese og understøtter tidligere forskning der finder at reduktion er en hæmmende faktor $i$ perceptionen af ord (bl.a. Ernestus et al. 2002, Tucker 2011 og Ejstrup \& Blom 2015). Det er dog værd at bemærke at lytterne i det hele taget som oftest svarede korrekt på såvel distinkte som reducerede stimuli. Så selvom reducerede ord var lidt sværere for lytterne at processere, idet det tog dem længere tid at genkende ord med reducerede intervokalisk /g/ end med distinkt /g/, gjorde reduktion langt fra genkendelsen af ordene umulig.

I undersøgelsen blev der benyttet to mål for reduktionsgrad, et kategorisk og et kontinuert. Det kategoriske var en binær distinktion mellem reduceret og distinkt, mens det kontinuerte var baseret på forskelle i intensitet. Begge mål viste sig at være signifikante, både i modeller der analyserede svartider, og modeller for svarkorrekthed. Det at intensitetsforskel var signifikant i modelleringen af både reaktionstider og svarkorrekthed, peger på at målet ikke bare er et praktisk akustisk korrelat til den traditionelle kategorielle skelnen mellem distinkt og reduceret, men at segmentel reduktion også i spørgsmålet om perception bør opfattes som et graduelt snarere end et diskret fænomen i studier af taleprocessering.

Undersøgelsen havde også som mål at undersøge om ordfrekvens spiller en rolle når lyttere processerer ord. Eftersom undersøgelser fra 
flere sprog har påvist højere tendens til reduktion i hyppige ord end i sjaldne ord, kunne man forvente at lyttere ville have nemmere ved at genkende reducerede former af højfrekvente ord end reducerede former af mellem- og lavfrekvente ord, simpelthen fordi de oftere møder disse ord i reducerede former i løbende daglig tale. Vi fandt dog at der ingen forskel var på reducerede og distinkte ord med hensyn til ordfrekvens hvor man kunne have forventet en krydseffekt. Man kunne have forventet at ordfrekvens ville kompensere for reduktion, sådan at højfrekvente ord med reducerede lukkelyde ville være nemmere at genkende end lavfrekvente ord med reducerede lukkelyde, fordi højfrekvente ord oftere realiseres med reducerede segmenter i løbende tale. Det var imidlertid ikke den effekt vi fandt. Samtidig viste det sig i svartidsresultaterne at ord på frekvensniveauet 'mellemfrekvent' var dem lytterne havde nemmest ved at genkende, mens de i gennemsnit var lige lang tid om at genkende højfrekvente og lavfrekvente ord. Dette resultat forekommer i første omgang overraskende da det ikke passer med de tendenser der ses i taleproduktionsundersøgelser. Imidlertid stemmer resultatet overens med Tucker (2011) der fandt nøjagtigt det samme mønster for svartiderne, altså at svartiderne for amerikanske lyttere også var kortere for mellemfrekvente ord end for høj- og lavfrekvente. Som Tucker (2011) også påpeger, indikerer dette at den fundne effekt er et resultat af forsøgsdesignet: Vi udsættes normalt ikke i daglig tale for lige store andele af høj-, mellem- og lavfrekvente ord, idet højfrekvente ord forekommer endog meget hyppigere end både mellem- og lavfrekvente. Når lytterne i dette forsøg er blevet udsat for (næsten) lige store andele af ord fra de tre frekvenskategorier, er det muligt at de har tilpasset sig denne distribution, hvilket betyder at perceptionsapparatet indstilles på at forvente at møde mellemfrekvente ord. Forsøgsdeltagerne optimerer så at sige deres svar for ord med den mest sandsynlige eller "centrale" frekvens sådan at genkendelsen af mellemfrekvente ord bliver optimeret. I de tilfælde hvor de faktisk blev eksponeret for et mellemfrekvent ord, har det faciliteret afgørelsen af om en stimulus var et ord eller ej, mens det ved eksponering for høj- eller lavfrekvente ord har hæmmet ordgenkendelsesprocessen.

En lignende effekt er blevet fundet for taleproduktion: Tabak et al. (2010) fandt at talere hurtigere producerede mellemfrekvente verber 
end høj- og lavfrekvente verber i en benævnelsesopgave. Sammenholdt med det resultat at det lineære graduelle mål for ordfrekvens ikke havde en statistisk signifikant effekt på svartiderne, tyder undersøgelsen dog på at ords hyppighed ikke spiller en nævneværdig rolle i genkendelsen af ord i spontantale. Det ville dog være interessant at følge op med en undersøgelse hvor distributionen af ord mht. frekvens lå tættere på den som lyttere møder i daglig tale. Man kunne også overveje et forsøgsdesign hvor informanterne fordeles på tre grupper der testes med stimuli der befinder sig i hvert deres frekvensniveau. En sammenligning på tværs af grupperne ville kunne fortælle om ordfrekvensen har indflydelse på processeringen af såvel distinkte som reducerede ordformer.

I svarkorrekthedsmodellerne er det med hensyn til det kategoriske mål for ordfrekvens, Frekvensniveau, kun de lavfrekvente ord der er signifikant forskellige fra de andre frekvensniveauer, således at der var større sandsynlighed for at svare forkert på de lavfrekvente ord end på de højfrekvente og de mellemfrekvente ord. Selvom vi kan se at der var flere korrekte svar ved de mellemfrekvente ord end ved de højfrekvente ord, er denne forskel ikke statistisk signifikant. Det kontinuerte mål for ordfrekvens, Logtransformeret frekvens, som i svartidsmodellerne viste sig ikke at have nogen effekt, er imidlertid signifikant i modellerne for svarkorrekthed sådan at jo højere frekvens et ord har, des større sandsynlighed er der for at lytteren svarer korrekt på det. Til trods for manglende signifikans i det kategoriske mål for ordfrekvens ser svarkorrekthedsmodellerne altså ud til at pege på det simple og forventelige resultat at ordfrekvens har en positiv effekt på genkendelsen af ord. Således er der større sandsynlighed for at svare korrekt på de ord man ofte hører, end de ord man sjældent hører når man modellerer ordfrekvens som et graduelt fænomen, mens det tilsyneladende ikke påvirker hvor hurtigt sprogbrugeren processerer ordene.

Eftersom denne undersøgelse analyserer og beskriver sprogbrugerens processering (af reduktion), går den ind i en tilbagevendende psykolingvistisk debat om hvordan sprogbrugerens leksikon og dets grundlæggende mekanismer bedst modelleres. Undersøgelsens hovedresultat er at sprogbrugere processerer reducerede ordformer langsommere og med flere fejl end ikkereducerede former, altså at reduktion udgør en 
hæmmende faktor i perceptionsprocessen. Dette resultat giver belæg for at operere med en mere abstrakt model af taleprocessering idet det peger på at der ikke er direkte adgang fra den konkrete ordform til det mentale leksikon, men at der foregår abstraktion af talesignalet forud for leksikalsk adgang: Når de reducerede ord genkendes med lavere hastighed end de distinkte, er det et tegn på at de først skal "oversættes" til en underliggende form i leksikonet. De distinkt udtalte ord er derimod identiske med (eller ligger i det mindste meget tæt på) den underliggende form hvis man antager at denne er den distinkte, og lyttere derfor processerer dem hurtigere. En mere konkret orienteret model kan ikke umiddelbart forklare at en specifik form har en særlig status fordi det antages at individet lagrer al den akustiske information (eksemplarer) som han/hun gennem sin levetid er stødt på, i det mentale leksikon, og at det akustiske input i perceptionsprocessen knyttes direkte til de lagrede eksemplarer og altså ikke skal omsættes til en anden form. Man kunne dog overveje, hvis man igen tager fat i forholdet mellem taleproduktion- og perception, om den lagrede form er den form af et ord der er hyppigst i produktionen. Denne undersøgelses resultater giver en idé om at de underliggende former er distinkte, men det behøver de ikke at være; svarkorrekthedsmodellerne peger jo netop på at frekvenseffekter spiller ind i perceptionen ved at ord med højere hyppighed er nemmere at genkende. Det kan være at det er meget få højfrekvente ord der har en reduceret form som deres mest almindelige manifestation, og at vores stimuli kun indeholdt en lille andel af højfrekvente ord med reduktion som den dominerende form, hvorfor der ikke viste sig en mindre effekt af reduktion ved processeringen af de højfrekvente ord. Det ville i så fald tyde på at processeringen ikke er helt abstrakt, og at en psykolingvistisk model for taleprocessering bør være hybrid så den inkluderer elementer fra både abstrakte og konkrete teorier. Det er imidlertid ikke særligt sandsynligt at den manglende krydseffekt i svartidsmodellerne skyldes en ujævn fordeling af reducerede og distinkte underliggende former, givet det man ved om reduktion og ordfrekvens - nemlig at reduktionsfænomener typisk og ofte rammer højfrekvente ord. Desuden har vi slet ikke mulighed for at afgøre hvilke ord der har henholdsvis distinkte eller reducerede dominerende former fordi vi ikke har den oplysning om vores stimuli; 
at bestemme deres underliggende former vil kræve en anden undersøgelse. Resultaterne peger altså på at den distinkt udtalte ordform er den underliggende, og de taler dermed overvejende for abstrakte modeller af taleprocessering. Dog peger svarkorrekthedsresultaterne også på at taleprocesseringen skal modelleres med supplerende inddragelse af teorier der fremsætter en mere konkret og detaljeret repræsentation af ord i det mentale leksikon.

Frekvenseffekter er også relevante for diskussionen om hvorvidt udtalevariation er drevet af taleren eller lytteren, såkaldte taler- og lytterorienterede teorier. Talerorienterede teorier antager at talere gerne vil reducere så meget som muligt for at være artikulatorisk økonomiske, hvilket kræver en indsats fra lytteren som skal tilpasse sig outputtets svagere akustiske cues. Lytterorienterede teorier går ud fra at taleren kun forsøger at reducere enheder lytteren nemt kan identificere for at opretholde en gnidningsløs kommunikation sådan at han/hun yder en indsats for at tilvejebringe et forståeligt talesignal (Ernestus 2014). Den lytterorienterede fremstilling af udtalevariation er desuden $i$ overensstemmelse med Lindbloms (1990) Hyper- \& Hypospeech-teori der hævder at taleren tilpasser talestilen i kraft af de gældende kommunikative og situationelle krav. I denne undersøgelse fandt vi imidlertid ingen krydseffekt for reduktion og ordfrekvens. Det vil sige at ordfrekvens ikke kompenserer for reduktion på en måde så lyttere har lettere ved at genkende højfrekvente reducerede ord end lavfrekvente reducerede ord - de har bare i det hele taget nemmere ved at genkende højfrekvente ord. Resultaterne støtter således ikke lytterorienterede teorier ud fra hvilke man ville have forventet at resultaterne for perception af reducerede ord ville afspejle mønstrene i produktionen.

Resultaterne ser i stedet ud til at understøtte talerorienterede teorier på samme måde som resultaterne i Tucker (2011) og Ernestus \& Baayen (2007). De talerorienterede teorier understøttes desuden yderligere af den u-formede kurve for effekten af frekvens i svarkorrekthedsmodellerne som netop peger på at lytterne optimerer deres svar til den aktuelle opgave. Det er lytteren der er vant til at skulle tilpasse sig talesituationen, ikke taleren. Den situation informanterne i denne undersøgelse har været i under forsøget, er selvfølgelig langt fra en reel kommunikationssituation mellem en taler og en lytter, og den tale 
de hørte, blev produceret til formålet. For at be- eller afkræfte teorierne må man således tage udgangspunkt $\mathrm{i}$ mere spontantalelignende forhold. Processeringen af ord foregår jo almindeligvis ikke $i$ isolation, som det var tilfældet $i$ dette forsøg. Det er derfor nødvendigt at undersøge reducerede former i forhold til kontekstuelle faktorer som den omgivende ytrings fonetik, syntaks, semantik og talestil for bedre at belyse forholdet mellem reduktion og perception. Desuden tager undersøgelsen udgangspunkt i ét reduktionsfænomen ud af mange og undersøger blot ét segment i én særlig struktur; flere forsøg er således nødvendige for at afdxkke fonetisk reduktion med alle dets facetter og tilvejebringe mere generaliserbare resultater.

$\begin{array}{lll}\text { Nicolai Pharao } & \text { Mia Ridder Malmsted } & \text { Selina Veng } \\ \text { Institut for Nordiske } & \text { Institut for Nordiske } & \text { Institut for Nordiske } \\ \text { Studier og Sprogvidenskab } & \text { Studier og Sprogvidenskab } & \text { Studier og Sprogvidenskab } \\ \text { Københavns Universitet } & \text { Københavns Universitet } & \text { Københavns Universitet } \\ \text { nicolaip@hum.ku.dk } & \text { mia.r.m@hotmail.com } & \text { selinaveng37@hotmail.com }\end{array}$




\section{LITTERATUR}

Baayen, R.H. 2008. Analyzing linguistic data. Cambridge: Cambridge University Press.

Boersma, P. \& D. Weenink. 2015. Praat: Doing phonetics by computer (5.4.21). [Computerprogram].

Bybee, J. 2002. Word frequency and context of use in the lexical diffusion of phonetically conditioned sound change. Language variation and change 14. 61-290.

Ejstrup, M. \& J.N. Blom. 2015. Hvad eller va: Indholdsgenkendelse af meget bogstavnær og mindre bogstavnær udtale i dansk mediesprog. Journalistica 1. 24-51.

Ernestus, M., Baayen, R.H. \& Schreuder, R. 2002. The recognition of reduced word forms. Brain and language 81. 162-173.

Ernestus, M. \& R.H. Baayen. 2007. The comprehension of acoustically reduced morphologically complex words: The roles of deletion, duration, and frequency of occurrence. J. Trouvain, W.J. Barry (red.), Proceedings of the 16th International Congress of Phonetic Sciences, Saarbrücken, 6-10 August 2007, 773-776. Saarbrücken: Universität des Saarlandes.

Goldinger, S. D., 1996. Auditory lexical decision. Language and Cognitive Processes 11(6). 559-567.

Grønnum, N. 2005. Fonetik \& fonologi. København: Akademisk Forlag.

Grønnum, N. 2009. A Danish phonetically annotated spontaneous speech corpus (DanPASS). Speech communication 51(7). 594-603.

Heegård, J. 2013. Morphologisation or reduction by context? The -te ending on adjectives and preterite verb forms in Standard Copenhagen Danish. Acta linguistica Hafniensia 45(1). 100-125.

Heegård, J. 2015. Ordvarighed og grammatisk og pragmatisk funktion. Tilfældet egentlig. NyS 49. 61-97.

Heegård, J. \& J. Thøgersen 2016. Transskriptionspålidelighed på dansk: en undersøgelse af enighed i auditiv, fonetisk transskription af spontant talt dansk. Danske talesprog 16. 1-34.

Janse, E., S.G. Nooteboom \& H. Quené. 2007. Coping with gradient forms of /t/deletion and lexical ambiguity in spoken word recognition. Language and cognitive processes 22(2). 161-200.

Johnson, K. 2004. Massive reduction in conversational American English. K. Yoneyama \& K. Maekawa (red.), Spontaneous speech: Data and analysis. Proceedings of the 1st Session of the 10th International Symposium, 29-54. Tokyo, Japan: The National International Institute for Japanese Language.

Johnson, K. 2005. Decisions and mechanisms in exemplar-based phonology. M. Sole, P. S. Speeter \& M. Ohala (red.), Experimental approaches to phonology, 25-40. Oxford: Oxford University Press. 
Jurafsky, D., A. Bell, M. Gregory \& W. Raymond 2001. Probabilistic relations between words: Evidence from reduction in lexical production. J. Bybee \& P. Hopper (red.), Frequency and the emergence of linguistic structur, 229-254. Amsterdam: John Benjamins Publishing Company.

Lindblom, B. 1990. Explaining phonetic variation: A sketch of the H\&H-Theory. W. Hardcastle \& J. Marshal (red.), Speech production and speech modelling, 403-439. Amsterdam: Springer Verlag.

Mitterer, H. \& M. Ernestus 2006. Listeners recover/t/s that speakers reduce: Evidence from /t/-lenition in Dutch. Journal of phonetics 34. 73-103.

Pharao, N. Upubliceret. LANCHART frequency list. Københavns Universitet.

Pharao, N. 2010. Consonant reduction in Copenhagen Danish: a study of linguistic and extralinguistic factors in phonetic variation and change. Ph.d.-afhandling. Københavns Universitet.

Pharao, N. 2011. Plosive reduction at the group level and in the individual speaker. W.-S. Lee, \& E. Zee (red.), Proceedings of the 17th International Congress of Phonetic Sciences. Hong Kong, 17-21 August, 1590-1593. Hong Kong: City University of Hong Kong.

Pierrehumbert, J.B. 2001. Exemplar dynamics: Word frequency, lenition and contrast. J. Bybee \& P. Hopper (red.), 2001. Frequency and the emergence of linguistic structure, 137-157. Amsterdam: John Benjamins Publishing Company.

R Development Core Team, 2015. R: A language and environment for statistical computing (3.0.3 Warm Puppy). [Computerprogram] R Foundation for Statistical Computing.

Schachtenhaufen, R. 2013. Fonetisk reduktion i dansk. Ph.d.-afhandling. Copenhagen Business School.

Sumner, M. \& Samuel, A. G. 2005. Perception and representation of regular variation: The case of final /t/. Journal of memory and language 53(2). 322-338.

Tabak, W., R. Schreuder \& R.H. Baayen 2010. Producing inflected verbs: A picture naming study. The mental lexicon 5(1). 22-46.

Tucker, B.V. 2007. Spoken word recognition and the reduced American English flap. Ph.d.afhandling. The University of Arizona.

Tucker, B.V. 2011. The effect of reduction on the processing of flaps and /g/ in isolated words. Journal of phonetics 39. 312-318.

Tucker, B.V. \& N. Warner 2010. Phonetic variability of stops and flaps in spontaneous and careful speech. Journal of the Acoustical Society of America 130. 1606-1617. 